\title{
ФОНЕТИЧНІ ОЗНАКИ ПІВНІЧНИХ ДІАЛЕКТІВ АНГЛІЇ
}

\section{Присяжнюк О. Я.}

\section{ВСТУП}

Це дослідження спрямоване на вивчення фонетичних характеристик, що відрізняють акценти північного регіону Англії від орфоепічної норми. Актуальність теми дослідження визначається тим, що для досягнення адекватного взаєморозуміння у зв'язку 3 варіативністю форм мови в різних діалектах національної мови виникає необхідність вирішення ряду проблем взаємодії лінгвістичних чинників літературної норми та регіональних діалектів у процесі мовної комунікації.

Онтогенез відмінності північних діалектів від інших варіантів англійської мови криється в періоді ще до становлення стандартної англійської, а також в періоді найбільш сильного скандинавського впливу, що чиниться на ці діалекти, що призводить до помітних лінгвістичних відмінностей варіантів цього регіону від діалектів центру та півдня Англії. Таким чином, занурюючись у різноманітність усної діалектно-забарвленої мови, логічно виникає питання, релевантне для умов міжкультурної комунікації, якого роду труднощі пов'язані 3 адекватним розумінням діалектно-забарвленої мови, і яким чином вимова північних діалектів впливає на сприйняття мови також носіями англійської мови.

Проблеми синхронічної та діахронічої фонології, питання вивчення літературного стандарту, дослідження соціальної та територіальної варіативності мови висвітлювалися багатьма лінгвістами. Безпосереднім вивченням особливостей північних діалектів займалися та займаються О. Бродовіч ${ }^{1}$, С. Дайер ${ }^{2}$, К. Уотсон ${ }^{3}$, А. Келлет ${ }^{4}$,

1 Бродович О.И. Английская диалектная вариативность: типологический и общетеоретический аспекты : автореферат ... д-ра, филол. наук.. Санкт-Петербург, 1991. $42 \mathrm{c}$.

${ }^{2}$ Dyer S. Dialect of the West Riding of Yorkshire. A short history of Leeds and other towns. Wakefield: S.R. publ., 1970. 142 p.

${ }^{3}$ Watson K. Phonological resistance and innovation in the North-West of England. English Today 86, 22.2. April 2006. P. 55-61.

${ }^{4}$ Kellett A. The Yorkshire Dictionary of Dialect, Tradition and Folklore. Smith Settle, 2002. 217 p. 
П. Ханібоун ${ }^{5}$, Дж. Уеллс ${ }^{6}$, М. Маковській ${ }^{7}$, М. Уейклін ${ }^{8}$ та інші, розглядаючи їх 3 фонетичного, лексичного та граматичного поглядів. Представляється необхідним зупинитися на уточненні деяких понять, прийнятих у роботі, а саме термінів - акцент та діалект. Як випливає 3 досліджень британського соціолінгвіста та фонетиста П. Традгілла ${ }^{9}$, акиент розглядається як тип вимови, а діалект як варіант мови, що має відмінності від мовної норми на вимовному, граматичному та лексичному рівнях. Під час встановлення ареалу розповсюдження сучасних північних діалектів у Великобританії за основу нами була прийнята класифікація діалектів, запропонована А. Еллісом та П. Традгіллом, які до північних діалектів відносили регіони Нортамберленд, Камберленд, Дарем, Уестморленд, Йоркшир, Ланкашир.

Об'єктом дослідження є діалектно-забарвлена мова носіїв північних акцентів Англії. Предмет дослідження - своєрідність та особливості сприйняття діалектно-забарвленої мови носіями англійської мови. Метою $є$ виявлення та аналіз характерних рис північних діалектів сучасної Англії.

Регіональні варіанти мови у Великобританії відображають культурну самобутність народу і часом грають більш важливу роль, ніж мовна норма. У мові як ієрархічній системі виділяють три дрібніших підсистеми або рівні: фонетична, лексична та граматична, які $\epsilon$ базовими компонентами будь-якої мови. Оскільки об'єкт дослідження розглядається як варіант мови / акцент, який має відмінності від орфоепічної норми на вимовному рівні, розвитку відносин акценту та літературної мови приділяється особлива увага. Аналіз характерних рис північних діалектів та їх зіставлення зі стандартною вимовною нормою в цьому дослідженні зачіпає систему звуків або фонологію мови (включаючи наголос, ритм та інтонацію), систему граматики і систему словникового складу мови або лексики та проводиться на основі робіт відомих діалектологів, таких як Дж. Уеллс ${ }^{10}$, M. Уейклін ${ }^{11}$, П. Традгілл ${ }^{12}$, О. Бродовіч ${ }^{13}$ та інші.

${ }^{5}$ Honeybone P. Lenition inhibition in Liverpool English. English Language and Linguistics, 5. 2. 2001. P. 213-249.

${ }^{6}$ Wells J.C. Accents of English: Vol. 1. An Introduction. Vol. 11. The British Isles. Cambridge university press, 1982. P. xix, $465 \mathrm{p}$.

7 Маковский М.M. Английская диалектология. Современные английские территориальные диалекты Великобритании. Москва : КомКнига, 2005. 84 с.

${ }^{8}$ Wakelin M.F. English Dialects. An introduction. London: The Athlone press, 1972. 207 p., map

Trudgill P. The Dialects of England. Oxford : Blackwell Publishers, 1990. P. 87.

${ }^{10}$ Wells J.C. British English pronunciation preferences: a changing scene. Journal of the International Phonetic Association, 2000. Mode Access: http://bell.phon.ucl.ac.uk/ home/wells /changingscene.pdf. 
Північні діалекти розвинулися із стародавнього нортумбрійського діалекту та включали Йоркширський, Ланкаширський і діалект, який пізніше став шотландським ${ }^{14}$. Спираючись на схему А. Елліса, північні діалекти поділяються на три підгрупи: 1) Нортамберленд (Northumberland), північний Дарем (N. Durham); 2) Південний Дарем (S. Durham), Камберленд (Cumberland), Уестморленд (Westmorland), північний Ланкашир (N. Lancashire), горбиста частина Вест-Райдінга в Йоркширі (West Riding in Yorkshire); 3) Іст Райдінг та Норт Райдінг в Йоркширі (East Riding and North Riding in Yorkshire), Манчестер (Manchester) $^{15}$. Такий поділ прийнято за основу в цій роботі. В роботі прийнятий синхронічний підхід до досліджуваного матеріалу, що становить повний опис діалекту без посилань на історичні факти, а звертає увагу на взаємозв'язок окремих особливостей всередині системи діалекту. Однак не можна забувати, що під час опису діалекту все ж необхідно враховувати всю перспективу його соціального та історичного розвитку, тому що, наприклад, звуки сучасного англійського діалекту тісно пов'язані зі звуками середньоанглійського та давньоанглійського періодів. Так, Дж. Уеллс виділяє два підходи до типології діалектів: структурний, спрямований на використовувані фонематичні системи; цей підхід вимагає статичного синхронического опису кожного акценту; традиційний, історичний, орієнтований на динамічні фонологічні правила або процеси, що вимагає динамічного опису становлення кожного акценту. Історичний підхід порівнює діахронічні звукові зміни, які відбулися в розглянутих акцентах. Недоліками такого підходу, на думку Дж. Уеллса, $є$ тенденція змішувати поняття діахронії та синхронії, а також відсутність можливості описувати лексико-фонетичні відмінності і переходи, наприклад, zebra зі звуком $[i:]$ або [e], envelope $3[e]$ або $[p]^{16}$.

3 лінгвістичного погляду населення Англії розділено більш-менш рівномірно між північчю та півднем. Отже, близько половини жителів

${ }^{11}$ Wakelin M.F. Discovering English Dialects. Aylesbury (Bucks): Shire Publications, 1978. 63 p., ill., map

${ }_{12}$ Trudgill P. Sociolinguistic Variation and Change. Edinburgh University Press, 2001. 224 p.

${ }^{13}$ Бродович О.И. Диалектная вариативность английского языка: аспекты теории. Ленинград, 1988.

14 Маковский М.М. Английская диалектология. Современные английские территориальные диалекты Великобритании. Москва : КомКнига, 2005. 84 с.

15 Маковский М.M. Английская диалектология. Современные английские территориальные диалекты Великобритании. Москва : КомКнига, 2005. 84 с.

${ }^{16}$ Wells J.C. British English pronunciation preferences: a changing scene. Journal of the International Phonetic Association, 2000. URL: http://bell.phon.ucl.ac.uk/home/wells/ changingscene.pdf. 
Англії говорять певною мірою на північному діалекті, за винятком невеликої кількості людей, що використовують RP (Received Pronunciation $)^{17}$.

\section{1. Відмінності північних діалектів на фонетичному рівні}

У центрі уваги в цій роботі знаходяться відмінності північних діалектів на орфоепічному рівні. Оскільки графства північної Англії розташовані не так далеко від кордону 3 Шотландією, вплив шотландського акценту найбільш помітно, хоча, безсумнівно, є багато особливостей вимови характерних тільки для регіонів півночі Англії. Північні акценти характеризуються ритмічністю вимови, короткими голосними, сильними, напруженими приголосними, що додає мові жвавості, енергії та ритму.

Оскільки голосні більшою мірою схильні до вільного варіювання $\mathrm{i}$ тому несуть інформацію територіального характеру, основні відмінності акцентів від RP полягають у вокалічній системі: як в кількісних характеристиках, так і в якісних показниках окремих звуків. Наведемо приклади фонетичних відмінностей в системі голосних (монофтонгов, дифтонгів) північних акцентів від Received Pronunciation, отриманих нами в процесі аналізу автентичних джерел.

Так, носії північних діалектів різного віку використовують короткий голосний [a] та в деяких випадках звук [ce] в таких словах, як grass, laugh, chance, branch, dance, тоді як на півдні використовується довгий голосний [a:]. Однак у поєднаннях asp, ass, ast вимова [a:] зазвичай відображається як [ce]: glass [glces], fast [fcest]. У закритому складі використовується довгий [a:] замість [æ], наприклад, у таких словах, як lad, sad, cat, lass, man. We managed [ma:nld3d] to save your main cabaret [Ka:bəre:] room ${ }^{18}$. You are the gaffer [ga:fa]. Nay, lad [la:d], thee carry [ka:ri] on ${ }^{19}$. Якщо голосний звук [a] йде за апроксимантом [w], то голосний реалізується як [ce]: warm [warm], warn [wern].

Короткий голосний [A] в Received Pronunciation реалізується як [p] в районах Йоркшира та Бредфорда: someone [sımwən] - ['svmwən], wonder ['wAndə] - ['wpnda], club [klsb] - [klpb] та інші. It was becoming [bikbmin] more and more industiralised ${ }^{20}$. I could start to understand

${ }^{17}$ Wells J.C. Accents of English: Vol. 1. An Introduction. Vol. 11. The British Isles. Cambridge university press, 1982. P. 349.

${ }^{18}$ Peter Kay's Phoenix Nights. The Complete Series Two / directed by Peter Kay; starring: Peter Kay, Dave Spikey. VCI, 2003. 145 min.

${ }_{19}$ The Full Monty / directed by Peter Cattaneo; starring: Robert Carlyle. $20^{\text {th }}$ Century Fox Entertainment, Inc., 1997. 91 min.

${ }^{20}$ Ibid. 
[ondadsta:nd] what the people were saying. I was ushered [pfad] forward by the pensioner ${ }^{21}$.

Завдяки дослідженням, проведеним ще в 1998 році Дж. Уеллсом виявляється, що перевагу молодь віддає північному варіанту. Статистика така, що 44\% людей, що народилися після 1973 року, вимовляють оne [wpn] та тільки $30 \%$ тих, хто народився в період 3 1954-1973 рр., використовують стандартну форму [wan]. Проголошення [v] замість [A] свідчить про відсутність різниці між такими парами слів, як put та putt в північних акцентах. Так, голосний RP [A] реалізується як [v]: love [1 $1 \mathrm{v}]-[1 \mathrm{vv}]$, blood [blıd] - [blvd], stuff [staf] - [stvf], puff [paf] - [pvf], custody ['kıstadI] - ['kvstadI], money ['munI] - ['mvnI]. Поєднання «о + носовий приголосний» також

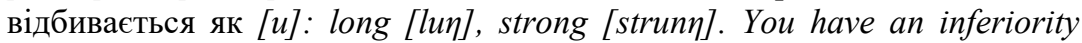
complex, that's why you play the drums [drvmz]. A month later I got all my redundancy [ridvndansI] money. One of my cousins [kvzans] was an inspector for a large bus company [bvs kvmpani] $]^{22}$.

Цю відмінність можна історично простежити на розпаді середньоанглійського короткого голосного [v] на дві фонеми. Це сталося географічно за трьома напрямами; на півдні Англії, в Уельсі та в Шотландії зараз $є$ система 3 шести коротких голосних, на півночі Англії була збережена система 3 п'яти голосних звуків, як це представлено в системі голосних по Дж. Уеллсу.

Відносно дифтонгів можна виділити наступні фонетичні особливості: низхідний дифтонг [eI] представляє або вузький дифтонг [гә], або відбувається стягнення дифтонга до монофтонга [e:]: plate [pleit] - [plet], mate [mert] - [met], bay [beI] - [be], але деякі слова, які мають у написанні eigh, вимовляються зі звуком [er] у північних акцентах, також як і в вимовній нормі: weight [weit]. It will not take [te:k] a minute. I'm gonna faint [fe: $n t]^{23}$.

She had this great [gre:t] big bowl.

Традиційна RP форма дифтонгу [ег] в діалекті Тайнсайд (Tyneside) [гә], яка відрізняється від форми прийнятої вимови і монофтонгу [e:], що $€$ «загальноприйнятим північним варіантом» (mainstream northern variant). У сучасній формі діалекту Тайнсайд традиційний дифтонг [eI] (як в слові face) використовується старшим поколінням, тоді як молодь вважає за краще загальноприйнятий надлокальний північний варіант

${ }^{21}$ Phinn G. The Other Side of the Dale. Penguin Audiobooks. Running time 3 hours

${ }^{22}$ Robbie Williams. The Show OFF Must Go On. BBC. 2004. 40 min.

${ }^{23}$ The Full Monty / directed by Peter Cattaneo; starring: Robert Carlyle. $20^{\text {th }}$ Century Fox Entertainment, Inc., 1997. 91 min. 
(випадок діалектального вирівнювання) $)^{24}$. Бажання молодого покоління звучати так, як сучасні жителі півночі, які усвідомлюють «старомодні» фонетичні риси, є результатом втрати одного 3 маркерів, що характеризують та безпомилково визначають носіїв північно-східного регіону.

Позиційна RP форма дифтонгу [3v] також є вузьким дифтонгом або монофтонгом [o:]: boat [bзvt] - [bs:t], nose [nзvz] - [ns:z], але багато слів 3 диграфом ow або ои в написанні, в вимові, навпаки, матимуть короткий монофтонг [v]. Таким чином, слова nose та knows не є омонимами. Ця відмінність втрачається, бо молоде покоління сіверян все частіше використовує дифтонг [3v] для обох пар слів. У таких словах, як cow, brown, house, зазвичай вимовляється дифтонг [av], але іноді в деяких районах півночі Англії можна почути довгий монофтонг [a:] - caa, braan, haas. У словах nurse та square використовується довгий монофтонг [з:] та більш передньоязикові [ع:] відповідно. У промові робітничого класу для обох груп слів використовується один

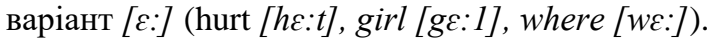

Комбінація $a+k$ реалізується як дифтонг [aI] або [eI]: back [berk] / [bark]; black [bleIk] / [blaIk]. Голосний $i$ перед nd відбивається як короткий [I]: blind [blin], find [fin], а в поєднанні 3 ld та ight реалізується як довгий [i:]: child [tfi:ld]. T'water in t'hen coops froz up last night [ni:t]. You were all reight [ri:t] though ${ }^{25}$.

Голосний $i$, який реалізується як дифтонг [aI] у літературному варіанті, вимовляється [эI]: five [forv], like [lork], time [torn]. Поєднання «ol + приголосний» реалізується як «[ou] + приголосний»: gold [goud], holt [out].

Система англійського консонантизму є історично більш стійкою. Приголосні виконують основну інформаційну функцію, забезпечуючи ідентифікацію слова, а значить і сенс висловлювання. Основні відмінності приголосних північних акцентів від RP простежуються в наступному. У багатьох північних графствах, особливо в Йоркширі, Ланкаширі та північному Мідленді, вибуховий альвеолярний $[t]$ в односкладових словах з коротким кореневим голосним на кінці слова переходить в альвеолярний апроксимант [ג], якщо таке слово в реченні або наступний склад у слові починаються з голосного звуку: get them ['ge.ıт], let it be [lesit'bi:], в двоскладових словах з наголосом на другий склад (delete, excite, allot ...), а також у фразові дієслова за умови, якщо головний наголос припадає не на дієслово, а на

${ }^{24}$ Watson K. Phonological resistance and innovation in the North-West of England. English Today 86, 22.2. April 2006. P. 55-61.

${ }^{25}$ Phinn G. The Other Side of the Dale. Penguin Audiobooks. Running time 3 hours 
прийменник (put it 'down, але не 'fit her). Цей процес обмежений лексично та не відбувається у прикметників, іменників, але нелексичні категорії (not, but, what, that) потрапляють під цей перехід.

Британські лінгвісти по-різному визначають це явище переходу вибухового альвеолярного в альвеолярний апроксимант. Професор Дж. Уеллс ${ }^{26}$ називає правилом 'T-R' те, що у П. Кара (Сагг) $\epsilon$ 'послабленням', у Дж. Біла (Beal) - 'вимова $[t]$ як $[r]$ '. У промові носіїв північних варіантів мови відбувається свідоме використання цього процесу (на відміну від використання аспірації або глотталізаціі). Експеримент частотності використання цього феномена показав, що в мові жінок робітничого класу використовується варіант альвеолярний апроксимант $[\wedge]$, середній клас та більш молоде покоління вимовляють миттєвий альвеолярний $[r]$. Традиційний територіальний поділ діалектів на південні та північні у разі з явищем переходу $[t]$ в $[r]$ також проводить відмінності у вимові: «там, де ледачі жителі півдня, особливо на Бі-Бі-Сі, опускають приголосний, сіверянин замінює його на альтернативний приголосний ' $r$ ': norra nother one!» ${ }^{27}$

У Вест-Райдінгу (в який входить Бредфорд) та в інших районах Йоркшира, дзвінкі вибухові $[b, d, g]$ стають глухими вибуховими $[p, t, k]$, якщо після них йде глухий приголосний. Відбувається редукція / приглушення приголосного. Так, Bradford вимовляється як ['brcetfad], а

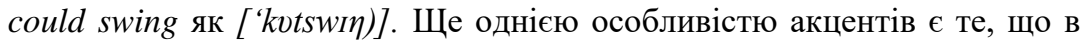
них часто зберігаються риси, втрачені нормою або навпаки: вимовляються ті звуки, які в літературному варіанті відсутні. Так, в інтервокальному положенні $[d]$ з подальшим $[r]$ реалізуються як дзвінкий фрикативний [ð]: powder ['pa:ðə], ladder [la: ðə]. 3 іншого боку, в ряді слів спостерігається реалізація зубних [б, $\theta]$ як альвеолярного $[d]$ в середині слова та в початковій позиції: father ['fa:də], together [to'gedə].

Північно-англійській діалектальний район характеризується тим, що там зустрічається гортанна смичка перед голосними та на кінці слова поряд $з$ преаспіраціей глухих проривних $[p, t, k$, ]: that all [ðəРっ:l, now what [nvvwa?], Feet [fi:?], leak [li:P]. Millenium did not [didn?] Have a title. I'm putting that [pv?Ingðce?] in the song. I wanted to sing that song

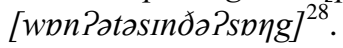

${ }^{26}$ Wells J.C. British English pronunciation preferences: a changing scene. Journal of the International Phonetic Association, 2000. Mode Access: http://bell.phon.ucl.ac.uk/ home/wells/ changingscene.pdf.

${ }^{27}$ Honeybone P. Lenition inhibition in Liverpool English. English Language and Linguistics, 5.2. 2001. P. 213-249.

${ }^{28}$ Robbie Williams. The Show OFF Must Go On. BBC. 2004. $40 \mathrm{~min}$. 
У разі гортанної змички перешкода повітряному потоку створюється в результаті змички голосових зв'язок ${ }^{29}$. Така реалізація $\epsilon$ найбільш поширеним фонетичним процесом, який відбувається в багатьох варіантах британської англійської, хоча, судячи з опису Пітера Традгілла, наявність гортанної змички в мові носіїв північних діалектів було помічено лише в середині минулого століття. $€$ думка, що твердий приступ є «одна 3 найбільш ганебних рис британської англійської». Звідси виникає нове твердження, що всі акценти стають все більш схожими на Estuary English, де ця особливість є типовою рисою. Закінчення -ing вимовляється як [in] або [ing]: coming [kpmin]. Зустрічається також повтор форми слова, наприклад, в singing [singin], хоча частіше в таких формах використовується велярно-носова / альвеолярно-носова зміна, singing [singin]. How tha' doing [dvin]? I'm putting [pvtıng] that in the song $[s p \eta g]^{30}$. Фрікативне $[h]$ зазвичай опускається (особливо перед гласним звуком): come here [kpmiə], ask him [pskim], hell [el]. Happy to help [elp].

Me hands [a: $n d z]$ have all melted. I was born in Hardwick [a:dwIk] $]^{31}$.

В той же час дуже поширене приєднання до слів, які починаються 3 голосного, неетимологічного $[h]$, наприклад, hobstinit (= obstinate), hawful (= awful). Початкове поєднання $\mathrm{cl}$ переходить в [tl]: clad [tlad], climb [tlim]; gl - в [dl]: glad [dlad], glass [dlas]. Початкове sh перед голосним відображається як [sk]. У ряді випадків паралельно існують варіанти $з$ [J] та [sk].

Латеральний альвеолярний $[l]$ в середині слова не вимовляється в поєднаннях $l d, l f, l h, l p, l s, l t$. Are you all right [o:ri:t] $?^{32}$

You almost [o:most] had it all. She were always [o:we:z] shouting ${ }^{33}$.

Не можна залишити без уваги той факт, що в середині XX століття міста півночі Англії були центром регіональних стандартів, а на цей час північні акценти конкурують та стикаються 3 впливом не тільки вимовної норми Received Pronunciation, але і модифікованого типу вимови Estuary English.

Дж. Брук стверджує, що англійські діалекти дуже впливають на стандартний англійський ${ }^{34}$. Говорячи про акценти, прикладом впливу

${ }^{29}$ Валиев С.А. Рефлексы смычно-гортанного слогового акцента литературного английского языка и в северноанглийских и южноанглийских диалектах Великобритании. Вопросы фонетики, диалектологии и истории языка. Лингвистическое исследование. Т.1 М., 1976. С. 14-29.

${ }^{30}$ Robbie Williams. The Show OFF Must Go On. BBC. 2004. $40 \mathrm{~min}$.

${ }^{31}$ Peter Kay's Phoenix Nights. The Complete Series Two / directed by Peter Kay; starring: Peter Kay, Dave Spikey. VCI, 2003. 145 min.

${ }^{32}$ The Full Monty / directed by Peter Cattaneo; starring: Robert Carlyle. $20^{\text {th }}$ Century Fox Entertainment, Inc., 1997. 91 min.

${ }^{33}$ Phinn G. The Other Side of the Dale. Penguin Audiobooks. Running time 3 hours

${ }^{34}$ Brook G.L. English Dialects. Blackwell, 1978. P. 35. 
північних акцентів на прийняту вимову може слугувати зміна в вимові довгого звуку [o:] в RP на [p]. Спочатку слова off, lost, cross вимовлялися 3 коротким [p]. Потім відбулося подовження до [ว:] в південних англійських акцентах та RP. Проте процес змін пішов у зворотний бік, і початкова коротка форма відновлюється. Однак довга голосна [0:] зберіглася та проявляється в мові середнього класу, оскільки варіанти проголошення подібних слів 3 довгим голосним типові для представників нижчих шарів робітничого класу, а серед мовців на RP - для консервативних або аристократичних шарів.

У дослідженні Дж. Уеллса простежується зв'язок цієї тенденції з територіальним варіюванням. Майже $80 \%$ респондентів, що живуть на півночі Англії та Уельсу, вважають за краще короткий звук $[p]$ у слові halt, а звук [0:] більш характерний для жителів півдня Англії. Крім того, майже $60 \%$ молодого покоління використовують короткий гласний в цьому слові, тоді як люди старшого покоління вважають за краще звук [о: $]^{35}$.

Однак вплив, який чиниться північними акцентами на прийняту вимову, не такий вже й великий. Деякі вчені стверджують, що останні роки були відзначені спадом у використанні традиційних діалектів північного регіону. М. Уейклін ${ }^{36}$ заявляє про поступове руйнування регіонального діалекту під впливом стандартної англійської. Автор акцентує увагу на тому, що регіональний діалект найкраще зберігається в сільській місцевості, хоча і там він схильний до руйнування. Навіть у тих регіонах, де продовжують говорити на діалекті, його жителі стають носіями двох діалектів, тобто використовують діалект у своїй місцевості, а стандартну англійську - далеко від дому або «на благо оточуючих».

\section{2. Особливості північних діалектів на лексичному та граматичному рівнях}

Традиційно вивченням змін, що відбуваються в територіальних діалектах, займаються такі британські дослідники, як Дж. Уеллс, Дж. Чамберз, П. Традгілл ${ }^{37}$, Дж. Чешір ${ }^{38}$, Д. Крістал ${ }^{39}$, Д. Джонс ${ }^{40}$, у

${ }^{35}$ Мошнина Т.В. Динамика современной произносительной нормы английского языка. Сборник научных трудов МГЛУ. Звучащая речь: теория и практика. Вып. 453. Москва, 2000. С. 131-140.

${ }^{36}$ Wakelin M.F. English Dialects. An introduction. London : The Athlone press, 1972. 207 p., map.

${ }^{37}$ Chambers J.K., Trudgill P. Dialectology. Cambridge : Cambridge University Press, 1998. 224 p.

${ }^{38}$ Cheshire J. Variation in an English dialect. A sociolinguistic study. Cambridge University Press, 1982. 142 p. 
чиїх працях найбільш повно висвітлена специфіка відмінності між літературною мовою та діалектом на всіх трьох мовних рівнях фонетичному, лексичному та граматичному. Незважаючи на те, що об’єктом дослідження є акценти північної Англії, важливим з погляду складності сприйняття діалектної мови $є$ розгляд невідповідностей лексико-граматичних форм зі стандартним варіантом англійської мови, оскільки в мові носіїв регіональних акцентів неминуча поява характерних діалектних рис.

Слова 3 культуроспеціфічними значеннями відображають та передають не тільки спосіб життя, характерний для певного суспільства, але також і спосіб мислення ${ }^{41}$. Традиційні терміни і фрази, асоційовані 3 Північчю Англії, в основному взяті зі сфер життя робітників у сільській місцевості: фермерство, рибальство, гірська промисловість. Лінгвісти, що досліджують питання в області лексики англійської мови, стверджують, що саме на півночі Англії зустрічається найбільше запозичених скандинавських елементів. У територіальних діалектах північної Англії і зараз багато скандінавізмів, які не зустрічаються в літературній мові. В.Н. Ярцева наводить такі приклади: dag - роса (сканд. dogg), frosk - жаба (сканд. froskr) та ін ${ }^{42}$. Крім того, північні діалекти мають оригінальну лексику, використовувану в побутовій сфері, спеціальні форми вираження вітання, прощання (напр. tarra sithee) та інше. Під впливом стандартної англійської регіональні діалекти поступово розмиваються; жителі стають носіями двох діалектів. Регіонально марковані слова не тільки повністю зникають 3 мови молодого покоління, що живе в сільських регіонах, змінюють значення (wireless - radio), але i схильні до заміни на більш універсальні завдяки мові реклами (sand shoes, pumps, plimsolls trainers $)^{43}$. Основними джерелами тиску на діалекти вважають засоби масової інформації, соціальні зміни, географічну мобільність населення, систему освіти, а також соціальне відношення. Змінюються не тільки слова або їх зміст, але відбувається їх зникнення 3 мови, «вимирання». Фахівці попереджають, що діалекти найближчим часом помітно зміняться, «деградують», і тому закликають до можливо $429 \mathrm{p}$.

${ }^{39}$ Crystal D. Cambridge Encyclopedia of the English Language. Cambridge, 1995.

${ }^{40}$ Jones D. English pronouncing dictionary / edited by Peter Roach \& James Hartman. $15^{\text {th }}$ ed. Cambridge Univ. Press 1997. 559 p.

${ }^{41}$ Вежбицкая А. Понимание культур через посредство ключевых слов. Москва : Языки славянской культуры, 2001. С. 57.

42 Ярцева В.Н. Развитие национального литературного английского языка. Изд. 2-е, испр. Москва : Едиториал УРСС, 2004. 288 с.

${ }^{43}$ Brook G.L. English Dialects. Blackwell, 1978. 232 p. 
повного фіксування їх актуального стану. Вони наполягають на необхідності захисту та збереження лінгвістичного різноманіття, оскільки втрата мови або діалекту є збіднінням того шляху, який пройшло людство, і може сприйматися як посягання на права людей, які розмовляють цією мовою або на цьому діалекті ${ }^{44}$.

Однією 3 основних причин, яку пропонує автор словника йоркширського діалекту А. Келлет ${ }^{45}$, через яку варто вивчати регіональні діалекти, $\epsilon$ те, що вони зберігають вимову, лексичний склад, граматику більш ранніх етапів історії мови. Діалекти не можуть бути збережені або існувати штучно. На них повинні говорити, якщо хочуть, щоб вони вижили. Автор вважає, що XXI століття найімовірніше буде століттям дедалі більшої однорідності, а отже монотонності. На противагу інтернаціоналізму та стандартизації, пропонується заохочувати регіональність 3 відмінною промовою, традицією і фольклором.

Граматичні особливості північних діалектів включають у себе вживання особливих дієслівних форм та займенників, змішання однини та множини, подвійне заперечення, використання дієслів 3 прийменниками. Відмінності, що стосуються морфологічних змін, можуть бути згруповані таким чином: випадки наявності або відсутності допоміжного дієслова та випадки відсутності узгодження між підметом і присудком.

У першій групі допоміжне дієслово do та дієслово to be в минулому невизначеному часі не узгоджуються 3 підметом. Дієслово to be в минулому невизначеному часі приймає множинну форму were 3 підметом в однині і навпаки. Допоміжне дієслово $d o$ не узгоджується 3 особистими займенниками he, she, it, таким чином, відсутня відмінність між допоміжними do та does. Допоміжне дієслово відсутнє в питальних реченнях та під час формування справжнього продовженого часу.

Характерною рисою другої групи відмінностей $\epsilon$ відсутність узгодження між підметом та присудком. Незважаючи на те, що іменник стоїть у множині, дієслово може йти в однині і навпаки. Крім того, відсутнє узгодження дієслів в розділових питаннях. Незважаючи на велику кількість відмінностей між нестандартними формами англійської мови та літературним стандартом, у кожного діалекту $є$ певний набір граматичних правил і структур.

${ }^{44}$ Barbour S. Accents, dialects and languages: National differences in the evaluation of language varieties. Sociolinguistics. Tubingen, 2002. № 14. P. 5-10.

${ }_{45}$ Kellett A. The Yorkshire Dictionary of Dialect, Tradition and Folklore. Smith Settle, 2002. $217 \mathrm{p}$. 
Найбільш помітні відмінності між сучасними північними діалектами і стандартною англійською полягають у наборі граматичних характеристик.

You coming? What you want? Where you go $?^{46}$.

У питальних пропозиціях та під час побудови форми дієслова в теперішньому продовженому часі спостерігається відсутність допоміжного дієслова. В цих випадках використовується зміна інтонації для того, щоб скласти питальне речення. I know it do not look good $^{47}$. He do not even like staying at yours ${ }^{48}$.

У негативних пропозиціях у 3-ї особи однини загальновживаною $є$ форма дієслова don't. У стандартній англійській $є$ різниця між допоміжними дієсловами $d o$ i does. Відсутність дієслова to be в теперішньому продовженому часі дозволяє розглядати цю форму як діалектальне відхилення від стандарту, де цей продовжений час утворюється за допомогою допоміжного дієслова to be та дієслова із закінченням -ing. I think this bugger sinking. You always necking me do stupid things ${ }^{49}$.

У північних діалектах відбувається узгодження дієслова у множині в минулому часі з підметом, що стоїть у третій особі однини. Однак підмет у множині приймає дієслово в однині. We was given a choice of moving areas.

Everybody knew where the children was. There was too many people living in Manchester itself ${ }^{50}$.

У північних діалектах простежується тенденція використання закінчення $-s$ для всіх осіб у цьому невизначеному часі: And I says to him: "Cheeky", meaning hard-faced naughty boy ${ }^{51}$. Відсутність узгодження між підметом та присудком є ще однією характеристикою північних діалектів: There is questions about your personal life. У стандартній англійській друга частина розділових питань узгоджується з основним дієсловом у розповідному реченні. Якщо перша частина питання стверджувальна, то дієслово у другій частині буде мати негативну форму. I навпаки, якщо перша частина питання негативна, то дієслово у другій частині має стверджувальну форму.

${ }^{46}$ Naked / directed by Mike Leigh; starring: David Thewlis, Lesley Sharp, Katrin Cartlidge. Fine Line Features, 1993. 131 min.

${ }_{47}^{47}$ Looking after Jo Jo / starring: Robert Carlyle. BBC, 1998. $202 \mathrm{~min}$.

${ }^{48}$ The Fifteen Street / directed by David Wheatley; starring: Sean Bean, Owen Teale, Clare Holman. Tyne Tees Television, 1989. $104 \mathrm{~min}$.

${ }^{49}$ The Full Monty / directed by Peter Cattaneo; starring: Robert Carlyle. $20^{\text {th }}$ Century Fox Entertainment, Inc., 1997. 91 min.

${ }^{50}$ Billy Elliot / directed by Stephen Daldry; starring: Julie Walters, Jamie Bell, Jamie Draven, Gary Lewis. Universal, 2000. 110 min.

${ }^{51}$ Robbie Williams. The Show OFF Must Go On. BBC. 2004. $40 \mathrm{~min}$. 
У північних діалектах та в розповідному реченні та в короткому питанні дієслово стоїть у позитивної формі. Навіть більше, також може бути відсутнім узгодження між формами дієслів. Yои are a doctor, are you? He is a nice old man, ain't he? Got to be very keen, are you? ${ }^{52}$

Певний артикль the втратив голосний, приголосні $[t, \theta]$ приєднуються до слова, яке йде за ним, наприклад, the man [tman, $\theta$ man]. Форма особистого займенника 1-ої особи однини в північних діалектах us використовується замість me: Give us a few. Send us some of them. Збереження в мові форми «thou»- займенники 2-ї особи однини підтверджує ідею консервативності діалектів.

Водночас, незважаючи на наявні відмінності діалектів від стандартної англійської, розглядаючи діалекти англійської мови крізь призму англійської як глобальної, можна припустити, що дрібні територіальні діалекти 3 часом зникнуть, так само як і існування універсальної мови може прискорити процес поступового зникнення мов національних меншин або зробити непотрібними всі інші мови. Феномен появи міжнародної англійської “International English" в рамках ділового співробітництва в світі свідчить про це. Д. Крістал, експерт у галузі мовознавства, має таке припущення: «Людині потрібна тільки одна мова, щоб говорити з собі подібними. Як тільки з'явиться всесвітня мова, інші просто зникнуть» ${ }^{53}$.

\section{ВИСНОВКИ}

У процесі дослідження ми дійшли висновку, що здійснюється взаємовплив акцентів, однак більшою мірою простежується вплив регіональних акцентів на норму, яка відбувається завдяки таким процесам, як:

- діалектальне вирівнювання. Освічені сіверяни перетинають лінгвістичний кордон «Північ-Південь», змінюючи свою вимову на користь прийнятої своєю чергою в мові багатьох освічених жителів півдня, визначаються характеристики північних акцентів. $\mathrm{y}$ лінгвістичних колах $є$ думка, що гегемонія прийнятої вимови RP слабшає;

- географічна дифузія - процес, за якого характеристики поширюються від найбільш населених, економічно та культурно домінуючих центрів. Інновація поширюється не рівномірно територією, а «стрибком» від центру джерела інновації до найближчого великого

${ }^{52}$ Billy Elliot / directed by Stephen Daldry; starring: Julie Walters, Jamie Bell, Jamie Draven, Gary Lewis. Universal, 2000. 110 min.

53 Кристал Д. Английский язык как глобальный. Москва : Весь Мир, 2001. C. 118 . 
міста, який стає вторинним центром цієї інновації, і вже 3 цього останнього - на більш дрібні поселення;

- зміна статусу "RP" як вимовної норми соціальної еліти. Вважаючи іiі архаїчною формою, як модель вибирається вимова дикторів телерадіокомпанії Бі-Бі-Сi, тому що мова цієї групи професіоналів не несе на собі ознаки привілейованості та статусу вищого класу;

- втрата престижності вимовної норми на тлі впливу та поширення Estuary English, що розвинувся на базі кокні та RP, у зв'язку 3 географічною мобільністю населення, а також широким використанням модифікованої форми вимови на радіо та телебаченні;

- джерело «змін знизу». Деякі зміни поширюються від людей нижчого соціального стану до вищого. Мова робітничого класу починає входити в моду і все більша кількість людей з вищих верств суспільства починає переймати їх фонетичні характеристики;

- молоде покоління яскравіше демонструє наростаючі тенденції, тоді як старше покоління демонструє явища більш консервативні. Молодь із заможних сімей, що володіє RP, схильна відчувати вплив «модних» на цей момент регіональних та соціальних типів вимови i діалектів, створюючи тим самим особливий, «молодіжний» варіант RP.

Отже, прийнята вимова конкурує та стикається iз впливом територіальних діалектів, доказом чого слугують процеси, що відбуваються в мові протягом останніх років. Виявлені зміни у фонетичній системі мови свідчать про еволюцію норми під впливом регіональних діалектів. Поняття Received Pronunciation розширюється шляхом включення більш широкого кола носіїв регіональних стандартів.

Системний опис особливостей північних діалектів на матеріалі звучних текстів, які зачіпають фонологію мови, систему граматики та лексики, та їх зіставлення зі стандартною вимовною нормою дозволяє нам стверджувати, що ця невідповідність буде приводити до серйозних труднощів сприйняття регіонального варіанту. Основні фонетичні та граматичні характеристики були проілюстровані прикладами 3 сучасних автентичних фільмів і аудіозаписів.

Особливості північних акцентів простежуються на орфоепічному рівні: кількісні та якісні характеристики голосних, монофтонгізація дифтонгів, опущення початкового фарингального приголосного, реалізація гортанної змички на кінці слів, заміна приголосних, наявність асимілятивних процесів. Основними лінгвістичними труднощами сприйняття усної мови на північному діалекті представляються також як граматичні, так і лексичні відхилення від стандарту, однак ці відмінності від літературної мови не настільки значні. 
Теоретичне значення роботи таке, що без урахування результатів такого аналізу уявлення про сучасну англійську діалектну ситуацію та особливості сприйняття діалектно-забарвленої мови виявляється неповним.

\section{АНОТАЦІЯ}

Це дослідження спрямоване на вивчення фонетичних характеристик, що відрізняють акценти північного регіону Англії від орфоепічної норми. Актуальність теми дослідження визначається тим, що для досягнення адекватного взаєморозуміння у зв'язку 3 варіативністю форм мови в різних діалектах національної мови виникає необхідність вирішення ряду проблем взаємодії лінгвістичних чинників літературної норми та регіональних діалектів у процесі мовної комунікації.

Регіональні варіанти мови у Великобританії відображають культурну самобутність народу і часом грають більш важливу роль, ніж мовна норма.

У статті були досліджені основні поняття, пов'язані 3 вивченням вимови, а саме норма, варіативність: просторова та соціальна. Будучи історичною, лінгвістичною та соціально-культурною категорією, норма характеризується стійкістю та динамізмом. Для виявлення фонетичних особливостей регіональної мови були докладно охарактеризовані форми існування мови в англійській мовній спільності: діалект, акцент, літературна мова, орфоепічні норма. Виявлені зміни у фонетичній системі мови свідчать про еволюцію норми під впливом регіональних діалектів. Поняття Received Pronunciation розширюється шляхом включення більш широкого кола носіїв регіональних стандартів.

\section{ЛІТЕРАТУРА}

1. Бродович О.И. Диалектная вариативность английского языка: аспекты теории. Ленинград, 1988.

2. Бродович О.И. Английская диалектная вариативность: типологический и общетеоретический аспекты : автореферат ... д-ра, филол. наук. Санкт-Петербург, 1991. 42 с.

3. Валиев С.А. Рефлексы смычно-гортанного слогового акцента литературного английского языка в северноанглийских и южноанглийских диалектах Великобритании. Вопросы фонетики, диалектологии и истории языка. Лингвистическое исследование. Т. 1. Москва, 1976. С. 14-29.

4. Кристал Д. Английский язык как глобальный. Москва : Весь Мир, 2001. 240 с. 
5. Маковский М.M. Английская диалектология. Современные английские территориальные диалекты Великобритании. Москва : КомКнига, 2005. 84 с.

6. Мошнина Т.В. Динамика современной произносительной нормы английского языка. Сборник научных трудов МГЛУ. Звучащая речь: теория и практика. Вып. 453. Москва, 2000. С. 131-140.

7. Скопинцева Т.С. Территориальная вариативность английской интонации на Британских островах (экспериментально-фонетическое иссл.) : дис ... канд. филол. наук. Москва, 1995. 19 с.

8. Степкина И.Ю. Просодические средства передачи эмоционально-модальных значений в спонтанной монологической речи современной молодежи Великобритании. Сборник МГЛУ. Проблемь современной фонетики. Вып. 507. Москва, 2005. С. 150-160.

9. Шевченко Т.И. Теоретическая фонетика английского языка: Учебник. Москва : Высшая школа, 2006. 191с.

10. Ярцева В.Н. Развитие национального литературного английского языка. Изд. 2-е, испр. Москва : Едиториал УРСС, 2004. 288 с.

11. Barbour S. Accents, dialects and languages: National differences in the evaluation of language varieties. Sociolinguistics. Tubingen, 2002. № 14. P. 5-10.

12. Billy Elliot / directed by Stephen Daldry; starring: Julie Walters, Jamie Bell, Jamie Draven, Gary Lewis. Universal, 2000. 110 min.

13. Brook G.L. English Dialects. Blackwell, 1978. 232 p.

14. Chambers J.K., Trudgill P. Dialectology / J.K. Chambers, P. Trudgill. Cambridge: Cambridge University Press, 1998. - 224 p.

15. Cheshire J. Variation in an English dialect. A sociolinguistic study / J. Cheshire. Cambridge University Press, 1982. 142 p.

16. Crystal D. Cambridge Encyclopedia of the English Language. Cambridge, 1995. 429 p.

17. Dyer S. Dialect of the West Riding of Yorkshire. A short history of Leeds and other towns. Wakefield : S.R. publ., 1970. 142 p.

18. Francis W.N. Dialectology. An introduction. London : Longman, 1983. $256 \mathrm{p}$.

19. Hedevind B. The dialect of Dentdale in the West Riding of Yorkshire. 1967. $350 \mathrm{p}$.

20. Honey J. Does accent matter? London, 1989. 208 p.

21. Honeybone P. Lenition inhibition in Liverpool English. English Language and Linguistics. 5.2. 2001. P. 213-249.

22. Jones D. English pronouncing dictionary / edited by Peter Roach \& James Hartman. $15^{\text {th }}$ ed. Cambridge Univ. Press 1997. 559 p.

23. Kellett A. The Yorkshire Dictionary of Dialect, Tradition and Folklore / A. Kellett. Smith Settle, 2002. 217 p. 
24. Looking after Jo Jo / starring: Robert Carlyle. BBC, 1998. 202 min.

25. Levey D., Harris T. Accommodating Estuary English / D. Levey, T. Harris. English Today 71. Vol. 18. № 3 (July 2002). P. 17-19.

26. Naked / directed by Mike Leigh; starring: David Thewlis, Lesley Sharp, Katrin Cartlidge. Fine Line Features, 1993. $131 \mathrm{~min}$.

27. Orton H., Dieth E. Survey of English dialects. The Basic Material / H. Orton, E. Dieth. Vol. I. The Six Northern counties and the Isle of Man. Leeds: Arnold, 1962. 335 p.

28. Peter Kay's Phoenix Nights. The Complete Series Two / directed by Peter Kay; starring: Peter Kay, Dave Spikey. VCI, 2003. 145 min.

29. Phinn G. The Other Side of the Dale / G. Phinn // Penguin Audiobooks. Running time approx. 3 hours

30. Robbie Williams. The Show OFF Must Go On. BBC. 2004. $40 \mathrm{~min}$.

31. The Fifteen Street / directed by David Wheatley; starring: Sean Bean, Owen Teale, Clare Holman. Tyne Tees Television, 1989. 104 min.

32. The Full Monty / directed by Peter Cattaneo; starring: Robert Carlyle. $20^{\text {th }}$ Century Fox Entertainment, Inc., 1997. 91 min.

33. Trudgill P. The Dialects of England. Oxford : Blackwell Publishers, 1990. $176 \mathrm{p}$.

34. Trudgill P. Sociolinguistic Variation and Change. Edinburgh University Press, 2001. 224 p.

35. Wakelin M.F. English Dialects. An introduction. London : The Athlone press, 1972. 207 p., map

36. Wakelin M.F. Discovering English Dialects. Aylesbury (Bucks): Shire Publications, 1978. 63 p., ill., map

37. Watson K. The Realization of final / $t$ / in Liverpool English. Durham Working Papers in Linguistics. № 8. 2002. P. 195-205.

38. Watson K. Phonological resistance and innovation in the North-West of England. English Today 86, 22.2. April 2006. P. 55-61.

39. Wells J.C. Accents of English: Vol. 1. An Introduction. Vol. 11. The British Isles. Cambridge university press, 1982. P. xix, 465 p.

40. Wells J.C. British English pronunciation preferences: a changing scene / J.C. Wells. Journal of the International Phonetic Association, 2000. Mode Access: http://bell.phon.ucl.ac.uk/home/wells/changingscene.pdf.

\section{Information about the author: Prysyazhnyuk O. Ya.,}

Candidate of Philological Sciences, Associate Professor at the Department of Foreign Languages for Humanities Facultie of the Faculty of Romance and Germanic Philology Odessa I. I. Mechnikov National University 2, Dvoryanska str., Odesa, 65000, Ukraine 